\title{
Edyta Głowacka-Sobiech, Twórcy polskiego skautingu - Olga i Andrzej Małkowscy, Wydawnictwo Poznańskie, Poznań 2003, ss. 283
}

Recenzowana książka stanowi cenna pozycję wzbogacającą naszą wiedzę na temat początków skautingu w Polsce. Ukazuje zmiany w naukach o wychowaniu, jakie zaszły na przełomie XIX i XX wieku w Polsce, zwłaszcza w kontekście zaistnienia zjawiska nazywanego ,nowym wychowaniem", a więc nurtu znaczonego naturalizmem, aktywnością, wolnościa czy też indywidualizmem. Istotnym elementem jest przedstawienie narodzin nowego ruchu na tle życia, działalności i myśli pedagogicznej Olgi i Andrzeja Małkowskich, uważanych za ,rodziców" polskiego skautingu.

Nadrzędnym celem przyjętym przez E. Głowacka-Sobiech jest szczegółowe i dogłębne wyczerpanie wybranego zagadnienia. Książka jest monografia o charakterze interdyscyplinarnym, a materiał historyczny został przez autorkę przeanalizowany pod kątem działalności pedagogicznej Andrzeja i Olgi Małkowskich.

Ponadto rzeczą niezmiemie ważną jest próba wyjaśnienia nazwy ruchu stworzonego przez Małkowskich - skauting czy też harcerstwo? W tym celu autorka sporo uwagi poświęca wyjaśnieniu przyczyn narodzin ruchu skautowego stworzonego przez generała $\mathrm{R}$. Baden-Powella, jak również jego związków z ruchem utworzonym przez Małkowskich. W swojej książce autorka udowodniła, że zarówno skauting, jak i harcerstwo wypłynęły z tego samego źródła - podręcznika Baden-Powella - a więc jako terminy pojęcia te moga być stosowane zamiennie, co zreszta sama autorka czyni.

Bazą źródłowa jaką posłużyła się E. Głowacka-Sobiech sa głównie materiały archiwalne, zdeponowane m.in. w zbiorach Archiwum Akt Nowych, Archiwum Polskiej Akademii Nauk, Biblioteki Uniwersytetu Jagiellońskiego, czy też $\mathrm{Mu}$ zeum Historycznego miasta Krakowa; źródła drukowane, czasopisma dotyczące przedmiotu badań, a więc prasa skautowa okresu międzywojennego; publikowane wywiady i wspomnienia. Ponadto autorka posłużyła się literatura przedmiotu uzupe- łniajac zdobyte informacje. Przekładów z literatury anglojęzycznej autorka dokonała osobiście, co znacznie podnosi wartość publikacji. Ponadto praca jest zaopatrzona w liczne aneksy oraz fotografie dodatkowo podnoszace walory książi.

Jak sama autorka wskazała we wstępie praca ma charakter komparatywny. Przyjęte przez autorkę ramy chronologiczne książki maja charakter umowny i sa ściśle powiązane z kolejnymi etapami życia Andrzeja i Olgi Małkowskich

Ksiażka „rządzi” układ chronologiczny. Składa się ona $\mathrm{z}$ trzech rozdziałów. Pierwszym rozdziałem autorka ma zamiar wprowadzić czytelnika w problematykę przedmiotu przedstawiajac sytuacje społeczno-polityczno-kulturalna na ziemiach polskich na przełomie XIX i XX wieku. Nie bez znaczenia jest cofnięcie się $w$ czasie nawet do okresu rozbiorów, kiedy to Polska została wymazana z mapy Europy dostajac się pod rzady Prus, Austrii i Rosji. Ukazane zostały w nim wpływy idei romantycznych i pozytywistycznych na społeczeństwo polskie. Przedstawia się tu wpływ nowych tendencji w naukach o wychowaniu na społeczeństwo, które pojawiły się w tym okresie. Wyjaśnia podstawowe hasła i założenia „nowego wychowania". Dowodzi, że jedynie w Galicji, gdzie Polacy uzyskali pozycje narodu współrządzącego przełom XIX i XX wieku mógł przynieść niebywały „urodzaj” organizacji i ruchów młodzieżowych. Autorka podzieliła je na trzy zasadnicze kierunki - sportowo-turystyczno-gimnastyczny; etyczno-odrodzeniowy i wojskowy. Ponadto wprowadza w zagadnienia najważniejszych organizacji, jakie powstały w Galicji - Polskie Towarzystwo Gimnastyczne "Sokół" powołane do życia $\mathrm{z}$ inicjatywy K. Żukotyńskiego i L. Goltentala, czy też „Eleusis” zainicjowane przez W. Lutosławskiego. Nie pomija Organizacji Młodzieży Niepodległościowej "Zarzewie" oraz Polskiego Zwiazku Wojskowego. Przedstawia powiązania, jakje łaczyły te organizacje.

W rozdziale pierwszym autorka sporo miejsca poświęca przybliżeniu czytelnikowi okoliczno- 
ści, jakie sprzyjały narodzinom skautingu oraz jego twórcy - R. Stephensonowi Smithowi Baden-Powellowi (1857-1941).

Rozdział drugi obejmuje życie i działalność Olgi i Andrzeja Małkowskich w latach 1888-1919. Po kolei przedstawia dzieciństwo, lata szkolne Olgi Drahonowskiej (później od 1913 roku Małkowskiej) oraz Andrzeja Małkowskiego. Opisuje wpływ, jaki na Olgę wywarła organizacja „Eleusis", jej uczestnictwo w kursach organizowanych przez „Zarzewie” i organizacji „Armia Polska". Przedstawia rolę i wkład Olgi Małkowskiej $w$ proces tworzenia organizacji żeńskich drużyn skautowych. Autorka szeroko przedstawia ewolucję poglaquów Andrzeja Małkowskiego i jego wkład w rozwój i działalność polskiego skautingu. Przybliża okoliczności nawiązania kontaktów z zagranica oraz tłumaczenie przez niego literatury anglojęzycznej zaopatrzonej własnymi komentarzami (m.in. podręcznik Beden-Powella). Przedstawia rolę, jaką pełnił będąc współredaktorem czasopisma ,Skaut”. Autorka przedstawiła także pogląd Małkowskiego na rolę i istnienie skautingu w Polsce. W ciekawy sposób opisała działalność Małkowskich w Zakopanem, gdzie urzeczywistniali swoje idee oraz wpływ, jaki I Wojna Światowa odegrała na ich dalszych losach. W tym rozdziale autorka zaprezentowała także działalność Małkowskich na emigracji - w Stanach Zjednoczonych i Kanadzie. Opisuje wkład jaki Andrzej Małkowski włożył w organizację „Legionu polskiego" oraz tzw. Oddziału „Straceńców”. Autorka przedstawiła różnice $w$ pogladach, jakie charakteryzowały władze organizacji oraz szeregowych członków. Ponadto zwróciła uwagę czytelnika na szerokie kontakty polityczne Andrzeja Małkowskiego i jego korespondencję z polskimi działaczami emigracyjnymi. Rozdział ten zakończyła na tragicznej śmierci Andrzeja Małkowskiego w 1919 roku.

Rozdział trzeci, obejmujący lata 1920 - 1979, można w zasadzie podzielić na trzy podrozdziały. Podrozdział pierwszy omawia okres dwudziestolecia miedzywojennego, kiedy to Olga Małkowska po powrocie do wolnej już Polski osiadła w Zakopanem, realizując ideę swoja i tragicznie zmarłego męża. W tym podrozdziale autorka omawia tzw. „zakopiański” okres działalności Małkowskiej, powstanie i działalność „Cisowego Dworku” w Sromoweach Wyżnych k. Czorsztyna oraz Harcerskiej Szkoły Pracy. Ponadto opisuje działalność nie tylko pedagogiczna Małkowskiej ale także jej aktywność w polskim i międzynarodowym ruchu skautowym. Wielokrotnie wskazuje na wybitny talent organizatorski Olgi Małkowskiej.

Drugi podrozdział obejmuje lata 1939 - 1945, a więc okres pobytu $O$. Małkowskiej poza granicami kraju, w Wielkiej Brytanii, gdzie udała się na przymusowa emigrację. Tam też aktywnie włączyła się w organizację opieki nad sierotami oraz organizację harcerstwa emigracyjnego.

Trzeci podrozdział obejmuje lata 1946-1979. W tym podrozdziale E. Głowacka-Sobiech omawia działalność opiekuńczo-wychowawczą Małkowskiej, jej dalszy udział w światowym ruchu skautowym oraz ostatnie lata życia, które spędziła już w Polsce.

Reasumujac, uznać należy pracę dr Edyty Głowackiej-Sobiech za bardzo znacząca w dorobku historii polskiego skautingu. Książka przekazuje wiedzę o poczatkach i rozwoju ruchu skautingu na ziemiach polskich w wyjatkowo przystępnej formie. Jest ona napisana językiem żywym i barwnym, zaopatrzonym w bardzo liczne cytaty. Można stwierdzić, że w istotny sposób wypełnia dotychczasową lukę $w$ badaniach nad problematyka ruchu skautowego w Polsce w kontekście ukazania kolei życia jego twórców. Nie bez znaczenia sa zawarte w pracy analizy i ustalenia. Autorka stara się w sposób obiektywny przedstawić poruszane zagadnienia, nie waha się pisać o tych lepszych i gorszych „obliczach" początków polskiego skautingu.

W mojej ocenie publikacja jest wyrazem rzetelności autorki, co także zasługuje na podkreślenie, a ksiażkę można polecić jako godna uwagi lekturę dla interesujących się poruszana problematyka.

Robert Jankowiak

*

Praca Edyty Głowackiej-Sobiech jest próba zarazem monograficznego i biograficznego ujęcia życia i działalności Olgi i Andrzeja Małkowskich, twórców skautingu w Polsce. Ramy chronologiczne pracy wyznaczaja $w$ zasadzie lata życia postaci, 1888 - 1919 dla Andrzeja i 1888 - 1979 dla Olgi. Oczywiście, jak przy większości ujęć 
biograficznych konieczne było poszerzenie tych ram o wydarzenia $z$ okresu wcześniejszego, związane z dziejami kraju i rodzin bohaterów książki.

Baza źródłowa pracy jest niezwykle szeroka. Została oparta na kwerendach zarówno $w$ archiwach polskich (Archiwum Akt Nowych, Archiwum Polskiej Akademii Nauk, Biblioteka Uniwersytetu Jagiellońskiego, Muzeum Historyczne m. Krakowa, Zakład Narodowy im. Ossolińskich we Wrocławiu, Muzeum Tatrzańskie im. Dra T. Chałubińskiego w Zakopanem), jak i w zagranicznych (Centralne Państwowe Archiwum Historyczne Ukrainy, Archiwum Wojewódzkie we Lwowie oraz Zbiory Polish Army Veterans Assn of America w Nowym Jorku). Ponadto autorka wykorzystała wiele źródeł drukowanych dotyczacych w szczególności zagadnień organizowania wychowania skautowego w Polsce i za granica.

Celem autorki, jak pisze we wstępie, była próba „zbadania życia i aktywności zawodowej Małkowskich $\mathrm{z}$ ukazaniem wkładu, jaki wnieśli oni do rozwoju nauk o wychowaniu i do praktyki edukacyjnej" oraz możliwości współczesnych zastosowań efektów ich pracy. Jednak opis biograficzny postaci posłużył tutaj do ogólniejszych rozważań dotyczacych dziejów rozwoju skautingu polskiego na szerszym tle międzynarodowym. Edyta Głowacka-Sobiech poruszyła następujące zagadnienia $\mathrm{z}$ tego zakresu:

- narodziny skautingu zachodniego $\mathrm{w}$ świetle nowych tendencji $w$ dziedzinie edukacji XIX i XX wieku,

- źródła specyfiki polskiego skautingu,

- polski ruch skautowy w przededniu odzyskania niepodległości (procesy integracyjne środowiska skautowego, przemiany ideału osobowego skauta, rozszerzanie grupy wychowanków),

- idee harcerskie Drugiej Rzeczypospolitej na tle ówczesnych koncepcji pedagogicznych,

- rozwój międzynarodowych spotkań skautowych i uczestnictwo w nich delegacji skautów polskich.

Swoje rozważania merytoryczne autorka podzieliła na trzy części. W pierwszej, zatytułowanej „Barwy epoki”, starała się przybliżyć czytelnikowi ogólną sytuację społeczną, kulturalną i polityczna ziem polskich pod zaborami z przełomu XIX i XX wieku. Sa to bowiem zagadnienia kluczowe dla zrozumienia mentalności Olgi i Andrzeja. Autonomia i specyfika Galicji, ożywiona działalność tamtejszych organizacji dla młodzieży oraz ścierające się wówczas idee pozytywistyczne i neoromantyczne wywarły duży wpływ na wybór ich drogi życiowej. Edyta Głowacka-Sobiech poruszyła problem wychowawczych aspektów jawnej i tajnej działalności grup samokształceniowych, gimnastycznych, wojskowych, niepodlegfościowych oraz moralizatorskich (abstynenckich). Ponadto przedstawiła krótka historię ruchu skautowego na Zachodzie w ramach tzw. ,nowego wychowania" wskazując wyraźnie kierunki przemian w postrzeganiu pozycji i zadań życiowych człowieka oraz rolę jaka w naukach o wychowaniu odegrał kult indywidualności.

W drugiej części skupiła się na prezentacji lat młodzieńczych swoich bohaterów, szczeblach ich edukacji i okresie wspólnej działalności na polu organizowania i popularyzowania skautingu w Polsce ${ }^{2}$. Podjęła temat dualistycznego ujęcia skautingu jako zbioru regulaminów i jako określonego programu wychowawczego oraz związanego z tym problemu dotyczącego sporów zwolenników i przeciwników dążenia skautów polskich do wstępowania w szeregi Legionów Polskich.

Część trzecia została poświęcona koncepcjom i formom działalności pedagogicznej Olgi

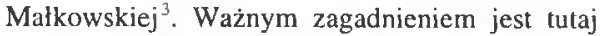
ukazanie stosunku skautingu do ogółu przemian społecznych związanych ze zmiana statusu kobiet oraz konkretnych rozwiązań w tym zakresie przyjętych przez organizatorów ruchu skautowego. Autorka wyróżniła tutaj trzy okresy:

- lata dwudziestolecia międzywojennego,

- okres wojny i okupacji 1939-1945,

- lata powojenne 1946-1979.

Rozróżnienie to wynika $z$ odmiennych dla każdej $z$ wyżej wymienionych faz uwarunkowań i form działalności bohaterki - od pracy pedagogicznej w Zakopanem i stworzonym przez siebie Dworku Cisowym poprzez działalność w harcerstwie emigracyjnym w okresie Il wojny światowej aż po powojenna pracę opiekuńcza $w$ Anglii i powrót do kraju.

Przyjęta przez autorkę chronologiczna koncepcja pracy jest zazwyczaj używana przy ujęciach biograficznych. Cezurę wewnętrzna wyznacza tutaj rok 1919 i to nic tylko jako data odrodzenia się niepodległej Polski po okresie zaborów i moment istotnych zmian dla możliwo- 
ści rozwoju skautingu w Polsce. Jest to bowiem także okres przełomowy w życiu Olgi, początek nowej jego fazy, fazy samotnego, po śmierci męża, poszukiwania drogi prowadzacej do realizowania planów i marzeń o „Rzeczypospolitej Lutyckiej". Podjęła ona wówczas zupełnie pionierska pracę na polu organizacji szkoły opartej w dużym stopniu na metodach wychowawczych zaczerpniętych właśnie z ruchu skautowego. Z tej perspektywy przyjęcie roku 1919 jako najważniejszej cezury wewnętrznej, oddzielającej dwie ostatnie części książi, jest głęboko uzasadnione.

Spośród podejmowanych przez Edytę Głowacka-Sobiech problemów można wyróżnić kilka głównych wątków dotyczących następujących zagadnien:

- dyskusji nad obliczem polskiego skautingu i nad tendencjami do organizowania go ściśle według wzorców angielskich ze szczególnym uwzględnieniem roli Andrzeja w tym procesie,

- prac nad przygotowywaniem i wdrażaniem w życie regulaminów życia skautowego,

- zasad i form organizacji działalności skautowej kobiet $\mathrm{z}$ wyraźnym zaznaczeniem pionierskiej na tym polu działalności Olgi,

- powstawania i rozwoju czasopiśmiennictwa i publikacji skautowych,

- współpracy i kontaktów skautów polskich z organizacjami skautowymi za granica.

Książka ta jest pierwsza całościową próba ukazania życia i działalności obojga Małkowskich, jednak szczególny nacisk autorka położyła na postać Olgi. Wynika to nie tylko $z$ faktu, iż działalność jej męża obejmowała znacznie krótszy odcinek czasu (do 1919 roku), lecz także wiąże się z tym, że praca Andrzeja częściej była przedmiotem zainteresowania osób badających zagadnienie skautingu polskiego.

Informacje zebrane na podstawie analizy rozproszonych materiałów ze spuścizny Małkowskich pozwalaja w pełni ukazać wkład Olgi w kontynuowanie i rozwijanie koncepcji męża oraz oddaja specyfikę działalności bohaterki jako „natchnienia dworkowego, wodza prowadzącego ludzi na szczyty (nie tylko tatrzańskie)", a nie pojmowanej w sposób tradycyjny nauczycielki i wychowawczyni ${ }^{4}$. Obrazuja także jej niesłabnące $\mathrm{z}$ czasem dążenia do poszerzenia grona wiernych zwolenników skautowych metod wychowawczych.
Edyta Glowacka-Sobiech przedstawiła w swojej pracy Olgę i Andrzeja jednocześnie jako pedagogów, teoretyków i praktyków. Z jednej strony opisała ich działalność w sferze organizowania drużyn, szkoleń i zjazdów skautów, a $\mathrm{z}$ drugiej ukazała dażenia podejmowane w celu propagowania tego stylu życia poprzez publikacje i artykuły w różnorakich czasopismach. Dokonała także analizy głoszonych przez Malkowskich koncepcji wychowawczych pod kątem ich uniwersalności i atrakcyjności dla dzisiejszej pedagogiki. Wszystko to złożyło się na interesująca biografię pedagogiczna twórców polskiego skautingu.

Ciekawym uzupełnieniem publikacji sq aneksy, na które składaja się głównie fragmenty publikacji Olgi i Andrzeja z czasopism skautowych, takich jak: „Skaut”, „Harcerz” i „Harcmistrz" oraz urywki z opracowanego przez Małkowskiego podręcznika dla skautów. Dotyczą one zarówno opisu koncepcji teoretycznych ich systemu wychowawczego, jak i relacji o przebiegu realizacji njektórych zamierzeń pedagogicznych. Zamieszczone na końcu spis ilustracji oraz indeks osobowy ułatwiaja czytelnikowi szybkie odnalezienie stosownych informacji. Książka zawiera również interesujace zdjęcia, które obrazuja życie rodzinne oraz działalność instruktorsko-wychowawczą bohaterów na niwie skautowej.

\section{Agnieszka Watęga}

${ }^{1}$ E. Głowacka-Sobiech, Twórcy..., s. 9.

2 Życie $i$ działalność pedagogiczna Olgi i Andrzeja Małkowskich w latach 1888-1919, s. 39-151.

${ }^{3}$ Kierunki i formy dziatalności oraz koncepcje pedagogiczne Olgi Matkowskiej w latach 1920-1979, s. $152-226$

${ }^{4}$ E. Głowacka-Sobiech, Twórcy..., s. 179-181. 